\title{
Pediatric Intoxication Cases Followed in the PICU; 2-year Experience
}

\section{Çocuk Yoğun Bakım Ünitesinde Takip Edilen Zehirlenme Olguları; 2 Yıllık Deneyim}

\author{
(D) Halil Keskin1, (D) Mustafa Kara2, (D) Hülya Akat2, (1) Naci Ceviz3 \\ ${ }^{1}$ Atatürk University Faculty of Medicine, Department of Pediatric Intensive Unit, Erzurum, Turkey \\ ${ }^{2}$ Atatürk University Faculty of Medicine, Department of Child Health and Diseases, Erzurum, Turkey \\ ${ }^{3}$ Atatürk University Faculty of Medicine, Department of Pediatric Cardiology, Erzurum, Turkey
}

\section{Abstract}

Introduction: There is no regional study presenting the pediatric intoxication cases followed in pediatric intensive care units (PICUs). As they show regional features, we aimed to present the pediatric intoxication cases followed in our PICU, and indicate our self-constituted protocol about the PICU admission rules in these patients.

Methods: Demographic, clinical and laboratory data of patients who admitted with intoxication and followed in PICU between October 2015 and October 2017 were noted. PICU admission indications were evaluated.

Results: Twenty-four (14\%) of the 171 intoxication cases formed the study group. Fourteen (58.3\%) were female. Ten cases $(41.7 \%)$ were under 5 years old, 6 (20.8\%) were $5-12$ years and 8 (37.5\%) were over 12 years. In first group, all intoxications were by accident. In second, intoxications were due to accident $(n=3)$, during drug use in treatment dose $(n=2)$ and as a result of child abuse $(n=1)$. In last group, it was by accident in 2, but as a result of suicide in 6 cases. Active ingredients were; central nervous system drugs ( $n=9)$, plant (atropa belladona) $(n=3)$, decongestant drugs $(n=3)$, multiple drugs $(n=4)$, intoxication by inhalation $(n=1)$ and other drugs $(n=4)$. Fifteen patients (62.5\%) had clinical indications for PICU admission. In five (20.8\%) the poison control center advised PICU admission. In four patients (16.7\%) we decided PICU admission because of the fatal nature of the ingested drugs.

Conclusion: Our results suggest that every clinic, by taking their availabilities into account, should form its own protocols for PICU admission for pediatric intoxication cases.

Keywords: Intoxication, pediatric intensive care, admission protocol

\section{Öz}

Giriş: Bölgemizde çocuk yoğun bakım ünitesinde (ÇYBÜ) izlenen çocuk zehirlenme olgularının sonuçlarını gösteren bir çalışma bulunmamaktadır. Bölgesel özellikler gösterdiğinden ÇYBÜ'de izlenen zehirlenme olgularını sunmayı ve bu hastalarda ÇYBÜ kabul kuralları hakkındaki kendiliğinden oluşan protokolü sunmayı amaçladık.

Yöntemler: Ekim 2015-Ekim 2017 tarihleri arasında çocuk acil kliniğine başvuran zehirlenme olgularından ÇYBÜ'ye yatırılanların demografik, klinik ve laboratuvar verileri hastane tıbbi kayıt sisteminden elde edildi. Hastalar ÇYBÜ'ye kabul gerekçeleri yönünden değerlendirildi.

Bulgular: Çocuk acil polikliniğine başvuran ve intoksikasyon tanısı alan 171 hastanın 24'ü (\%14) çalışma gurubunu oluşturdu. Hastaların 14'ü $(\% 58,3)$ kız çocuktu. Onu $(\% 41,7) 5$ yaş altında, altısı $(\% 20,8) 5-12$ yaş arasında ve sekizi $(\% 37,5) 12$ yaş üstündeydi. Beş yaş altındaki zehirlenmelerin tamamı kazara alınan ilaçlar sonucunda oluşmuşken, 5-12 yaş grubunda 3 olgu kazara alım, 2 olgu tedavi dozunda ilaç kullanımı ve bir olgu istismar sonucu oluşmuştu. On iki yaş üzerindeki hastaların 6'sı özkıyım amaçlı ilaç alımıyla ve 2'si kazara zehirlenmiş̧i. Etken maddeye göre gruplandırma yapıldığında zehirlenmelerden sorumlu maddeler aşağıdaki gibi idi; santral sinir sistemi ilaçları $(n=9)$, bitki $(n=3)$, dekonjestan ilaçlar $(n=3)$, çoğul ilaç $(n=4)$, inhalasyon zehirlenmesi $(n=1)$, diğer ilaçlar $(n=4)$. Klinik olarak yoğun bakım gereksinimi olan 15 hasta $(\% 62,5)$, zehir danışma merkezi tarafından yoğun bakım şartlarında takibi önerilmiş olan beş hasta $(\% 20,8)$ ve aldığı maddenin ölümcül olduğu tarafımızdan öngörülen ancak başvurusunda klinik olarak yoğun bakım ihtiyacı olmayan dört hasta $(\% 16,7)$ yoğun bakımda izleme alındı.

Sonuç: Elde ettiğimiz veriler her kliniğin kendi şartlarını dikkate alarak, zehirlenme olgularının hangilerinin ÇYBÜ'ye kabul edileceği ile ilgili protokollerini oluşturmaları gerektiğine işaret etmektedir.

Anahtar Kelimeler: Zehirlenme, çocuk yoğun bakım, kabul protokolü 


\section{Introduction}

Intoxication is a frequent and important problem in children. Although most children with intoxication are asymptomatic on admission, there might be life-threatening findings. ${ }^{1}$ Children with life-threatening conditions are followed in pediatric intensive care units (PICU). In their study including 12,021 children admitted to PICUs due to intoxication, Patel et al. ${ }^{2}$ reported that approximately $70 \%$ of children did not undergo any significant intervention. However, a reliable scoring system that can predict which children require PICU admission following acute intoxication has not been developed yet. ${ }^{2}$ Therefore, because of the nature of the ingested substances, many intoxication cases are being followed in PICUs, even if the patients are asymptomatic on admission.

In our region, none of the studies presented the results of pediatric intoxication cases followed in PICUs. As the intoxication cases show regional features, ${ }^{3}$ we aimed to present pediatric intoxication cases followed in our PICU.

\section{Material and Methods}

This study is designed as a single-center retrospective study (Atatürk University Faculty of Medicine, Department of Pediatrics). Patients who were admitted to the pediatric emergency department (PED) with the complaint of intoxication and patients in whom intoxication was diagnosed after admission based on other symptoms between October 2015 and October 2017 were included in this study. Medical records of these patients were evaluated and the clinical features of the ones who were followed in the PICU are presented. Age, gender, symptoms and signs on admission, substances responsible from intoxication, laboratory values, indications for PICU admission, applied treatments, length of stay in the PICU, total length of hospital stay and the outcomes were noted from the medical records.

Mean \pm SD was given for numerical data and number and percent were given for nominal data.

Approval for the study was obtained from the local ethics committee (2017/156). The study was conducted in accordance with the principles of the Declaration of Helsinki.

\section{Results}

A total of 171 children who were diagnosed with intoxication in the PED were hospitalised. Twenty-four (14\%) patients, who were admitted to the PICU (17 were admitted with the diagnosis of intoxication, 7 received the diagnosis after the first evaluation), formed the study group. Fourteen (58.3\%) of them were female.
Ten children (41.7\%) were under the age of 5, $6(20.8 \%)$ were $5-12$ years of age and $8(37.5 \%)$ were over 12 years. In the first age group, all patients had accidental intoxication. In the second, intoxications were due to accidental ingestion of medications ( $n=3)$, drug toxicity developing at therapeutic dose $(n=2)$ and as a result of child abuse $(n=1)$. In last age group, the cases were accidental poisoning in 2 (carbon monoxide intoxication $=1$, unconscious drug use for headache $=1$ ), and suicide-related self-poisoning in 6 patients.

The poisoning were caused by central nervous system drugs $(n=9)$, plant (atropa belladonna) $(n=3)$, decongestant drugs $(n=3)$, multiple drugs $(n=4)$, intoxication by inhalation $(n=1)$ and other drugs $(n=4)$ (Table 1$)$.

Fifteen patients (62.5\%) had clinical indications for follow-up in the PICU (Table 2, group 1). Five patients (20.8\%) did not have an indication for PICU admission clinically, but they were followed in the PICU because of the current status (given false or inadequate information to intensivist, unavailable intensivist consultation, etc.) (Table 2, group 2). The remaining four patients $(16.7 \%)$ did not have an indication for PICU follow-up clinically. We decided to follow these patients in the PICU before consultation with the poison control center (PCC) because of the fatal nature of the ingested drugs (colchicine, amitriptyline, Ca++ channel blocker and central nervous system (CNS) stimulant, CNS stimulant and antihistaminic) (Table 2, group 3).

The patients from group 1 had the lower Glascow coma scores (GCSs) (median=11, range $=5-15$ ) and higher pediatric risk of mortality (PRISM) scores (median $=7$, range $=0-13$ ). Four of 15 patients from group 1 (26.6\%) required an intervention that should be applied in the PICU (mechanical ventilation, noninvasive mechanical ventilation, high-flow nasal cannula (HFNC) and plasma exchange (PE). The median GCS was 13 (range=12-15) and median PRISM score was 1.5 (range=0-3) in group 2. None of these 5 patients needed an intervention that should be applied in the PICU. The median GCS was 14 (range=10-15) and median PRISM score was 2.5 (range= $0-3)$ in group 3. Only the patient with colchicine intoxication (Patient 14 with a GCS of 15) needed plasma exchange.

Seven patients did not have a history of intoxication. Except for the four patients who only had a drug/substance ingestion history but not any symptom (Table 3), all patients had one or more neurological signs (miosis, mydriasis, fixed and dilated pupils, confusion, delirium, lethargy, stupor, coma, dystonia, hyporeflexia, hyperreflexia, a positive Babinski sign, neck stiffness, convulsion). In addition, some patients had gastrointestinal $(n=3)$ (noisy, vomiting), cardiac $(n=4)$ (tachycardia, bradicardia, hypotension) and respiratory $(n=2)$ (bradipnea, tachypnea, superficial respiratory) symptoms and signs (Table 4). 
Table 1. Active ingredients that were responsible from intoxication

\begin{tabular}{|c|c|c|c|c|c|}
\hline Group & $\mathbf{n}$ & Subgroup & $\mathbf{n}$ & Active ingredients & $\mathrm{n}$ \\
\hline \multirow[t]{4}{*}{ CNS drugs } & 9 & Antiepileptic & 2 & Carbamazepine & 1 \\
\hline & & & & Clonazepam & 1 \\
\hline & & CNS stimulants & 1 & Methylphenidate & 1 \\
\hline & & TCA & 3 & Amitriptyline & 3 \\
\hline Decongestants & & & & Oksymetazoline & 1 \\
\hline \multirow[t]{3}{*}{ Multiple drugs } & 4 & & & Paracetamol, Nicotine, ASA, Ketoprofen & 1 \\
\hline & & & & Cetrizine + Paroxetine & 1 \\
\hline & & & & Olanzapine, Quetiapine, Risperidone + Citalopram & 1 \\
\hline \multirow{3}{*}{ Other } & & Symptomatic treatment for flu & 1 & Paracetamol, Chlorpheniramine, Oxalamine, Pseudoephedrine & 1 \\
\hline & & Mouse poison (anticoagulant) & 1 & Unknown & 1 \\
\hline & & Unknown & 1 & Unknown & 1 \\
\hline
\end{tabular}

Gastric lavage was applied in 9 patients in the first admission center $(n=4)$ and in our emergency department $(n=5)$. Gastric lavage was not applied in 7 patients due to absence of drug ingestion history and in 8 patients due to absence of indication (late admission=7, carbon monoxide intoxication=1). Activated carbon was given to 10 patients. To 4 of them (amitriptyline=3, colchicine=1), repeated doses were given after hospitalization. Activated carbon was not given to the remaining patients due to previous application, late admission or no need. No patient had a contraindication for activated carbon ingestion.

Plasma exchange was done in two patients (amitriptyline intoxication in group 1 and colchicine intoxication in group 3). Hyperbaric oxygen therapy was performed in a patient with carbon monoxide intoxication. A specific antidote was given to one patient with paracetamol intoxication.

Eight patients did not need oxygen. Oxygen inhalation was applied with a nasal cannula or mask in 12 patients and with HFNC in one patient. Respiratory support by noninvasive mechanical ventilation was needed in one and by conventional mechanic ventilation in 2 patients.

The wide QRS tachycardia in the patient with amitriptyline intoxication was diagnosed as ventricular tachycardia at the first admission and treated medically, but later it was decided that this was a result of the electrophysiological effects of the drug. It resolved spontaneously in time. One patient was incidentally diagnosed with Wolff-ParkinsonWhite syndrome.
In patient with colchicine intoxication, a mild elevation in transaminase levels and a mild thrombocytopenia occurred. Laboratory analyses were normal in other patients.

The mean length of stay in the PICU was 1.52 days (range=1-4 days), and the mean total hospitalization time was 3.58 days (range=1-15 days). The patients with colchicine and carbon monoxide intoxication had the longest stay in the PICU. No death occurred, and all patients were discharged without any sequel.

In 139 (94.6\%) of the remaining 147 patients, the PCC advised PICU monitoring. However, they were admitted to the general inpatient ward. None of them needed PICU followup after hospitalization, and all were discharged without any adverse event.

\section{Discussion}

Intoxication is a frequent childhood problem. Early and effective intervention that is lifesaving in some cases, reduces morbidity and mortality. "Early intervention" is understood as the first evaluation and treatment attempts by the medical team who see the patient first. In fact, at every step of the patient follow-up, when new negative conditions develop, urgent decisions should be made and effective interventions should be applied.

Intensive care units are essential for follow-up of patients with critical status, and they make early detection, effective treatment of new life threatening conditions and advanced life supports possible. 
The issue of which patients should be followed in the PICU in cases of poisoning is still a matter of debate. There is not a scale that may determine patients who should be followed in PICU. ${ }^{2}$ The PCC advices follow up in PICU in almost all intoxication cases. However, this is not possible in most of the pediatric clinics in all over the world. Our study gives important results that not all children with intoxication should be followed in PICU.

\section{Table 2. Clinical features of the children followed in PICU}

\begin{tabular}{|c|c|c|c|c|c|c|c|c|c|c|}
\hline Group & $\begin{array}{l}\text { Pt. } \\
\text { No }\end{array}$ & $\begin{array}{l}\text { Age } \\
\text { (years) }\end{array}$ & Gender & $\begin{array}{l}\text { Ingested } \\
\text { substance }\end{array}$ & $\begin{array}{l}\text { Cause of } \\
\text { intoxication }\end{array}$ & GCS & PRISM & $\begin{array}{l}\text { Procedure } \\
\text { required the } \\
\text { PICU follow } \\
\text { up }\end{array}$ & $\begin{array}{l}\text { PICU } \\
\text { days }\end{array}$ & $\begin{array}{l}\text { Total } \\
\text { hospitalization days }\end{array}$ \\
\hline \multirow{15}{*}{1} & 1 & 3.5 & $\mathrm{~F}$ & Plant & Accidentally & 13 & 3 & - & 1 & 2 \\
\hline & 2 & 1.1 & $\mathrm{~F}$ & CNS drug & Accidentally & 14 & 11 & MV-PE & 2 & 15 \\
\hline & 3 & 7.02 & $\mathrm{~F}$ & Multiple drug & Abuse & 9 & 8 & - & 2 & 3 \\
\hline & 4 & 2.56 & $\mathrm{~F}$ & CNS drug & Accidentally & 10 & 0 & - & 1 & 3 \\
\hline & 8 & 14.45 & $\mathrm{~F}$ & CNS drug & Suicide & 11 & 5 & - & 1 & 2 \\
\hline & 9 & 12.67 & $\mathrm{~F}$ & CNS drug & Suicide & 15 & 5 & - & 2 & 4 \\
\hline & 13 & 5.43 & $\mathrm{~F}$ & Plant & Accidentally & 12 & 0 & - & 1 & 2 \\
\hline & 15 & 13.91 & M & $\mathrm{CO}$ & Accidentally & 5 & 13 & HFNC & 4 & 14 \\
\hline & 16 & 5.35 & $M$ & Unknown & Accidentally & 6 & 5 & - & 1 & 3 \\
\hline & 17 & 5.75 & M & Decongestant & WTD & 13 & 3 & - & 1 & 2 \\
\hline & 18 & 5.14 & K & Plant & Accidentally & 13 & 5 & - & 1 & 2 \\
\hline & 19 & 1.76 & E & Decongestant & Accidentally & 10 & 8 & NIMV & 1 & 2 \\
\hline & 20 & 2.88 & E & CNS drug & Accidentally & 8 & 8 & - & 2 & 3 \\
\hline & 22 & 13.17 & E & CNS drug & Accidentally & 11 & 0 & - & 1 & 3 \\
\hline & 24 & 11.05 & E & Anti-flu drug & WTD & 5 & 2 & MV & 2 & 4 \\
\hline \multirow{5}{*}{2} & 10 & 14.92 & K & CNS drug & Suicide & 15 & 0 & - & 2 & 3 \\
\hline & 11 & 15.52 & K & Multiple drug & Suicide & 15 & 3 & - & 1 & 2 \\
\hline & 12 & 3.48 & E & Decongestant & Accidentally & 15 & 0 & - & 1 & 2 \\
\hline & 21 & 4.04 & E & CNS drug & Accidentally & 12 & 0 & - & 1 & 3 \\
\hline & 23 & 14.02 & K & Anticoagulant & Suicide & 15 & 0 & - & 1 & 2 \\
\hline \multirow{4}{*}{3} & 5 & 15.32 & K & Multiple drug & Suicide & 15 & 0 & - & 2 & 3 \\
\hline & 6 & 2.51 & K & CNS drug & Accidentally & 10 & 3 & - & 1 & 2 \\
\hline & 7 & 2.59 & K & Multiple drug & Accidentally & 13 & 3 & - & 1 & 4 \\
\hline & 14 & 3.46 & E & Alkaloid & Accidentally & 15 & 2 & $\mathrm{PE}$ & 4 & 5 \\
\hline
\end{tabular}

\section{Table 3. Patients who only had a drug/substance ingestion history but not have any symptom on admission}

\begin{tabular}{|c|c|c|c|c|}
\hline Pt. No & 9 & 11 & 14 & 23 \\
\hline Age (years) & 12 & 15 & 3 & 14 \\
\hline Gender & $\mathrm{F}$ & $\mathrm{F}$ & $\mathrm{M}$ & $\mathrm{F}$ \\
\hline Signs developed in PICU & Hypotension & None & None & None \\
\hline Days in PICU & 2 & 1 & 4 & 1 \\
\hline Specific treatment in PICU & Supportive treatment & $\begin{array}{l}\text { Supportive treatment + Antidote } \\
\text { (N-acetyl cysteine) }\end{array}$ & Supportive treatment + PE & Supportive treatment \\
\hline
\end{tabular}


Table 4. Detected clinical signs in terms of the ingested drug groups

\begin{tabular}{|c|c|c|c|c|}
\hline Group & n & Affected system & Signs & $\begin{array}{l}\text { GCS median } \\
\text { (Range) }\end{array}$ \\
\hline \multirow{4}{*}{ CNS drugs } & \multirow{4}{*}{9} & CNS & $\begin{array}{l}\text { Myosis, mydriasis, fix dilated pupil, confusion, delirium, lethargy, stupor, } \\
\text { coma, hyperreflexia, positive babinski, seizure, hypotermia }\end{array}$ & \multirow{4}{*}{$11(4-15)$} \\
\hline & & GIS & Nausea, vomiting & \\
\hline & & CVS & - & \\
\hline & & RS & - & \\
\hline \multirow{4}{*}{ Plants } & \multirow{4}{*}{3} & CNS & Mydriasis, lethargy, hallucination, delirium, neck stiffness & \multirow{4}{*}{$13(12-13)$} \\
\hline & & GIS & Nausea, vomiting & \\
\hline & & CVS & Flushing & \\
\hline & & RS & - & \\
\hline \multirow{4}{*}{ Decongestants } & \multirow{4}{*}{3} & SSS & Lethargy, delirium & \multirow{4}{*}{$13(10-15)$} \\
\hline & & GIS & - & \\
\hline & & CVS & Bradycardia, hypotension & \\
\hline & & SS & Superficial respiration, insufficient respiration & \\
\hline \multirow{4}{*}{ Multiple drug } & \multirow{4}{*}{4} & SSS & Myosis, confusion, lethargy, dystonia, seizure, positive Babinski & \multirow{4}{*}{$14(9-15)$} \\
\hline & & GIS & Nausea, vomiting & \\
\hline & & CVS & Tachycardia & \\
\hline & & RS & - & \\
\hline \multirow{4}{*}{ Inhaled } & \multirow{4}{*}{1} & CNS & Coma & \multirow{4}{*}{5} \\
\hline & & GIS & - & \\
\hline & & CVS & - & \\
\hline & & RS & - & \\
\hline \multirow{4}{*}{ Other } & \multirow{4}{*}{4} & CNS & Myosis, coma, hyporeflexia, hyperreflexia & \multirow{4}{*}{$10.5(5-15)$} \\
\hline & & GIS & - & \\
\hline & & CVS & - & \\
\hline & & RS & Bradypnea & \\
\hline
\end{tabular}

In the present study, $14 \%$ of our patients were admitted to the PICU at the first admission to PED. Of course, one can speculate that some of these patients do not have an indication for PICU admission. During this study, we have noted that we have acted according to a spontaneously developed protocol according to our own clinical conditions in terms of indications for PICU admission. Group 1 patients had clear indications for PICU admission. In our clinic, some interventions (i.e. plasma exchange) that could be necessary for group 3 patients can only be performed in the PICU, so we prefer to hospitalize such patients in the PICU at the first admission. The patients, for whom the PCC advised PICU admission but it was not approved by the consultant (139/147, 94.6\%), were not hospitalized in the PICU. For these patients, transfer to the PICU was always possible if needed. None of them needed PICU follow-up after hospitalization. The PCC makes recommendations according to the written criteria about the ingested substances, but they do not have the chance to evaluate the clinical findings of the patients. We assume that these patients should be evaluated by pediatric emergency teams and they should make the decision for PICU admission based on the recommendations of the PCC, the present clinical findings of the patients and the present conditions of the PICU. For some patients, as in group 2 patients, present status (false or inadequate information to given to intensivist, unavailable intensivist consultation, etc.) may result in unnecessary PICU admissions. This shows that unnecessary PICU admissions are inevitable in some pediatric intoxication cases.

In the literature, most of the pediatric intoxication cases have been reported to be evaluated, treated and discharged from PEDs. ${ }^{4,5}$ Our PED facilities are not suitable for such a clinical application, thus, we follow our patients in either general inpatient wards or PICU.

The GCS had been reported to be the single predictor of PICU requirement in adult drug overdose patients. ${ }^{6}$ Our results indicate that this may not be the case for children.

The demographic and clinical features of our patients (e.g. ingested substances, intoxication reasons, etc.) were similar to those presented in the literature. ${ }^{7-12}$ 
Among these, some are striking. Two patients aged 5-12 years developed toxic findings with therapeutic doses of decongestant and anti-flu drugs (Table 2, patient 17,24). These drugs are not routinely given to children. ${ }^{13}$ Our findings indicate that if used, one should be careful for their toxic effects. For example, patient 2 indicates that not all wide QRS tachycardias are ventricular tachycardia in patients with amitriptyline intoxications. ${ }^{14,15}$ In these patients, the surface electrocardiogram should be evaluated in detail before intensive treatment against ventricular tachycardia. In our study, $20.8 \%$ of 24 patients needed an intervention that should be performed in the PICU. This result is consistent with the results of Patel et al. ${ }^{2}$ obtained from 12021 intoxication cases.

\section{Study Limitations}

Relatively small sample size and its retrospective design are the limitations of our study.

\section{Conclusion}

Although our results support the idea that most of the childhood intoxication cases can be followed in an observation unit instead of the $\mathrm{PICU}^{8,16}$, we think that every clinic, by taking their facilities into account, should form its own protocols for PICU admission for pediatric intoxication cases.

\section{Ethics}

Ethics Committee Approval: Approval for the study was obtained from the local ethics committee (2017/156).

Informed Consent: Patient received approval.

Peer-review: Externally and internally peer-reviewed.

\section{Authorship Contributions}

Concept: H.K., M.K., H.A., N.C., Design: H.K., M.K., H.A., N.C, Data Collection or Processing: H.K., M.K., H.A., N.C, Analysis or Interpretation: H.K., M.K., H.A., N.C, Literature Search: H.K., M.K., H.A., N.C, Writing: H.K., M.K., H.A., N.C.

Conflict of Interest: No conflict of interest was declared by the authors.

Financial Disclosure: The authors declared that this study received no financial support.

\section{References}

1. Shannon M. Ingestion of toxic substances by children. $N$ Engl J Med. 2000;342:186-91.

2. Patel MM, Travers $C D$, Stockwell JA, Geller RJ, Kamat PP, et al. Analysis of Interventions Required in 12,021 Children With Acute Intoxications Admitted to PICUs. Pediatr Crit Care Med. 2017;7:e281-e9.

3. Govaerts-Lepicard M. Epidemiology in Childhood Poisoning: Implications in Prevention Planning. Clinical Toxicology. 1981 1981:18:1145-8

4. Nalliah RP, Anderson IM, Lee MK, Rampa S, Allareddy $\mathrm{V}$, et al. Children in the United States make closeto 200,000 emergency department visits due to poisoning each year. Pediatr Emerg Care. 2014;30:453-7.

5. Akgül F, Er A, Çelik FÇ, Çağlar A,Ulusoy E, ve ark. Çocukluk Çağ Zehirlenmelerinin Geriye Dönük Olarak Incelenmesi. J Pediatr Emerg Intensive Care Med. 2016;3:91-6.

6. Maignan M, Pommier P, Clot S, Saviuc P, Debaty G, et al. Deliberate drug poisoning with slight symptoms on admission: are there predictive factors for intensive care unit referral? A three-year retrospective study. Basic Clin Pharmacol Toxicol. 2014;114:281-7.

7. Even KM, Armsby CC, Bateman ST. Poisonings requiring admission to the pediatric intensive care unit: A 5-year review. Clin Toxicol (Phila). 2014;52:519-24

8. Fazen LE, 3rd, Lovejoy FH, Jr, Crone RK. Acute poisoning in a children's hospital: a 2-year experience. Pediatrics. 1986;77:144-51.

9. Hon $\mathrm{KL}$, Leung $T F$, Hung $\mathrm{CW}$, Cheung $\mathrm{KL}$, Leung AK. Ingestionassociated adverse events necessitating pediatric ICU admissions. Indian J Pediatr. 2009;76:283-6.

10. Lacroix J, Gaudreault P, Gauthier M. Admission to a pediatric intensive care unit for poisoning: a review of 105 cases. Crit Care Med. 1989:17:748-50.

11. Martin TC, Rocque MA. Accidental and non-accidental ingestion of methadone and buprenorphine in childhood: a single center experience, 1999-2009. Curr Drug Saf. 2011;6:12-6.

12. Ozdemir R, Bayrakci B, Teksam O, Yalcin B, Kale G. Thirty-three-year experience on childhood poisoning. Turk J Pediatr. 2012;54:251-9.

13. Miller EK, Williams JV. The Comnmon Cold. In:Kliegman RM, Stanton BF, St Geme JW, Schor NF (eds). Nelson Textbook of Pediatrics. 20th ed. Philadelphia, PA; 2016:2011-14.

14. Ceviz N, Olgun H. Amitriptilin Entoksikasyonuna Bağlı Geniş QRS Taşikardi. Türk Aritmi, Pacemaker ve Elektrofizyoloji Dergisi. 2011;9:141-44

15. Keskin $H$, Laloglu $F$, Yalçınöz $M O$, Kara $M$, Olgun $H$, et al. A Case of Severe Amitriptyline Intoxication: Electrocardiography Signs Suggesting Ventricular Tachycardia. West Indian Med J. DOI: 10.7727/WIMJ.2016.307

16. Plumb J, Dudley NC, Herman BE, Kadish HA. Utilization of a pediatric observation unit for toxicologic ingestions. Pediatr Emerg Care. 2012:28:1169-72. 